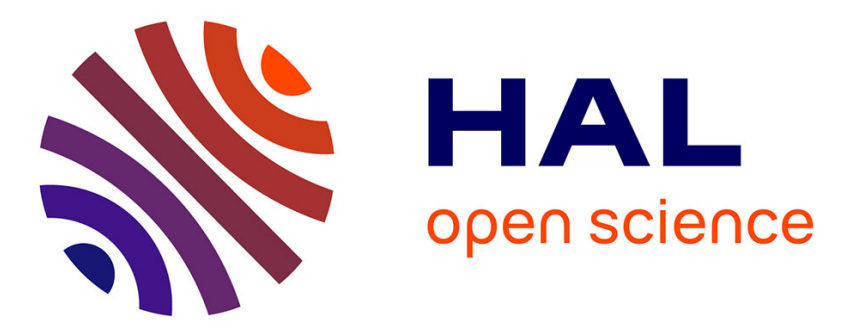

\title{
Environmental Support for Dilution of Pollutants from Broiler Production and Aquaculture in Brazil
}

Silvia H. Bonilla, Helton Silva, Robson P. Faustino, Irenilza De Alencar Nääs, Nilsa Duarte

\section{- To cite this version:}

Silvia H. Bonilla, Helton Silva, Robson P. Faustino, Irenilza De Alencar Nääs, Nilsa Duarte. Environmental Support for Dilution of Pollutants from Broiler Production and Aquaculture in Brazil. IFIP International Conference on Advances in Production Management Systems (APMS), Sep 2016, Iguassu Falls, Brazil. pp.99-105, 10.1007/978-3-319-51133-7_12 . hal-01615799

\author{
HAL Id: hal-01615799 \\ https://hal.inria.fr/hal-01615799
}

Submitted on 12 Oct 2017

HAL is a multi-disciplinary open access archive for the deposit and dissemination of scientific research documents, whether they are published or not. The documents may come from teaching and research institutions in France or abroad, or from public or private research centers.
L'archive ouverte pluridisciplinaire HAL, est destinée au dépôt et à la diffusion de documents scientifiques de niveau recherche, publiés ou non, émanant des établissements d'enseignement et de recherche français ou étrangers, des laboratoires publics ou privés.

\section{(c)(1)}

Distributed under a Creative Commons Attribution| 4.0 International License 


\title{
Environmental Support for Dilution of Pollutants from Broiler Production and Aquaculture in Brazil
}

\author{
Silvia H. Bonilla ${ }^{1}$, Helton R.O. Silva ${ }^{1}$, Robson P. Faustino ${ }^{1}$, Irenilza de Alencar \\ Nääs ${ }^{1}$, Nilsa Duarte ${ }^{2}$ \\ ${ }^{1}$ University Paulista, São Paulo, Brazil \\ ${ }^{2}$ State University of Campinas, Campinas, Brazil \\ shbonilla@hotmail.com
}

\begin{abstract}
Due to the rising demand for food, increasing intensive livestock production contributes significantly to the anthropogenic loading of the biosphere. Poultry and fish from intensive operations are a primary source for global human food consumption, and the contribution to air and water emissions. The environment can act as a sink of emissions by using it the capacity for diluting pollutants. In this way, the "support area" derived from the renewable resources supplied by region was quantified for both enterprises regarding emergy. Results suggest that poultry production seems to be a thousand times more "eco-efficient" than aquaculture as well as presenting a lower support area. Accounting for the environmental services required to dilute emissions is shown to be a necessary procedure towards the proper evaluation of long-term sustainability and quantification of externalities.
\end{abstract}

Keywords: Poultry $\cdot$ Aquaculture $\cdot$ Emergy $\cdot$ Environmental services

\section{$1 \quad$ Introduction}

Livestock production contributes significantly to the anthropogenic loading of the biosphere. As the world's demand for food increases, the increasing emissions to land, water and atmosphere from intensive livestock production is worthy of concern.

Poultry and fish from intensive operations are an important source for global human food consumption [1]. Aviaries are a source of ammonia emissions that are a function of $\mathrm{NH}_{3}$ concentration inside the housing. It depends on flock density, litter, diet and ventilation systems. Some of these parameters and consequently the ammonia emission can be controlled through proper management [2]. On the other hand, concerns are expressed about the discharge of wastes, increasing the concentration of nutrients, pathogens and chemical such as drugs and pesticides from aquaculture operation [3].

The environment can act as a source of resources and a sink of emissions. This might be accomplished by taking advantage of the current cycles and processes of the biosphere, and free environmental services. In this context, emissions from production process would rely on an amount of available resources (land, water, air) which acting as a sink will, at least, dilute them down to the biosphere background. In this way, the

adfa, p. 1, 2011.

(C) Springer-Verlag Berlin Heidelberg 2011 
"support area", would act as a buffered piece of land, with the capacity of providing the natural services necessary to dilute or abate emissions derived from any producer system. The problem arises with the establishment of the "support area" since natural services have to be quantified. The quantification of natural services taking into account their function and the involved support of the biosphere is not trivial, and the need for a well-established and well-sustained tool becomes evident.

This approach is provided by the emergy environmental accounting [4], an assessment framework that evaluates resources based on the environmental work required to generate them and make them available. The methodology, based on thermodynamics and systems theory, enables accounting for all natural and economic inputs entering a system in a common metric. It provides indices capable of quantifying environmental performance as well as monitoring improvements and it is a useful tool for decision making.

By quantifying the "work" of the biosphere involved in pollutants dilution (sun, wind, rain, deep heat, gravitational energy) in emergy terms, it is possible to make the conversion into the area of land demanded to supply those environmental services by the local renewable resources of the region $[5 ; 6]$.

This paper addresses the use of emergy to explore the role of natural services from a land area to act as a sink for ammonia emissions from a poultry production housing and phosphorous from an aquaculture farm. The environmental work done by the biosphere intending to dilute the considered emissions is accounted regarding emergy and converted to the "support area" concept, the land demand responsible for acting as a buffer.

\section{$2 \quad$ Methodology}

\subsection{Emergy Environmental Accounting}

Emergy accounting methodology [4] was developed over the last decades as a tool for environmental policy and to evaluate quality and distribution of resources in the dynamics of complex systems. A complete assessment of the methodology cannot be provided here, but the reader may refer to published reports [4; 7]. Briefly, emergy is defined as the sum of all inputs of energy (directly or indirectly) required for a process to provide a given product, when inputs are expressed in the same form (or type) of energy, such as solar energy [4].

The emergy flows are classified into three categories of resources: $\mathrm{R}$ as renewable resources, $\mathrm{N}$ as non-renewable resources and the inputs provided by the economy, $\mathrm{F}$. All three categories are fundamental to the emergy accounting and the understanding of the system interactions with the environment. $\mathrm{R}$ and $\mathrm{N}$ flows are provided by the environment and are economically free.

While renewable resources can be replaced at least at the same rate as they are consumed, the non-renewable resources are depleted faster than their ability of recuperation. The economic inputs, F, are provided by the market and are related to flows supplied by the economy. 
Every input has to be inventoried and multiplied by its correspondent "transformity" to calculate the emergy flows. "Transformity" (expressed in seJ/J) is the factor to convert each kind of energy in emergy, and it represents all past environmental work necessary to obtain one joule of a given resource. When inputs are expressed in units others than energy ones (mass or money), the UEV (unit emergy value) is used to convert values into solar energy joules (seJ). To carry out the emergy flux determination, the planetary baseline of $15.83 \times 10^{24} \mathrm{seJ} /$ year was adopted [8]. The transformity values that were calculated using another baseline were corrected and properly informed during calculation.

\subsection{Accounting for Environmental Services and Support Area}

The energy system diagram is described in Fig. 1. Inputs directly required to develop livestock production are aggregated into types, classified as $\mathrm{R}_{1}, \mathrm{~F}$ and $\mathrm{N}$, converging towards the inner frame. The outputs are food and waste by-products. The larger frame contains the environmental systems which act as the sink of the by-products also generated in the production system. The environmental services required to drive the dilution process are expressed as $\mathrm{R}_{2}$. The following steps were adopted to account for the environmental services:

(a) Determination of mass of air required to dilute $\mathrm{NH}_{3}$ and mass of water required to dilute phosphorous emissions for poultry production and tilapia aquaculture, respectively, up to acceptable concentration levels: (i) close to average values of $\mathrm{NH}_{3}$ in the biosphere, and (ii) phosphorous concentration in water below the critical threshold of eutrophication.

(b) Determination of the emergy flow of the required environmental services (noted as $R_{2}$ in Fig. 1) by calculating the kinetic energy of the mass of dilution air (measured as the wind power needed to spread and dilute pollutants) and the chemical energy of the mass of dilution water (Gibbs energy necessary to dilute pollutants). Procedures were adopted from [5; 9], respectively.

(c) Calculation of the "support area" (As), known as the area of land necessary to balance the emergy of the environmental services $\left(\mathrm{R}_{2}\right)$, and calculated from the average annual flux of renewable emergy per year per unit area of landscape $\left(E^{2} d_{R}\right)$, As $=$ $\mathrm{R}_{2} / \mathrm{Emd}_{\mathrm{R}}$ [5]. The value of $\mathrm{Emd}_{\mathrm{R}}$ was calculated from the results of the annually renewable emergy flows of Brazil, (extracted from [10]), divided by the Brazilian continental area and it accounts for $3.66 \times 10^{11} \mathrm{seJ} / \mathrm{m}^{2}$. 


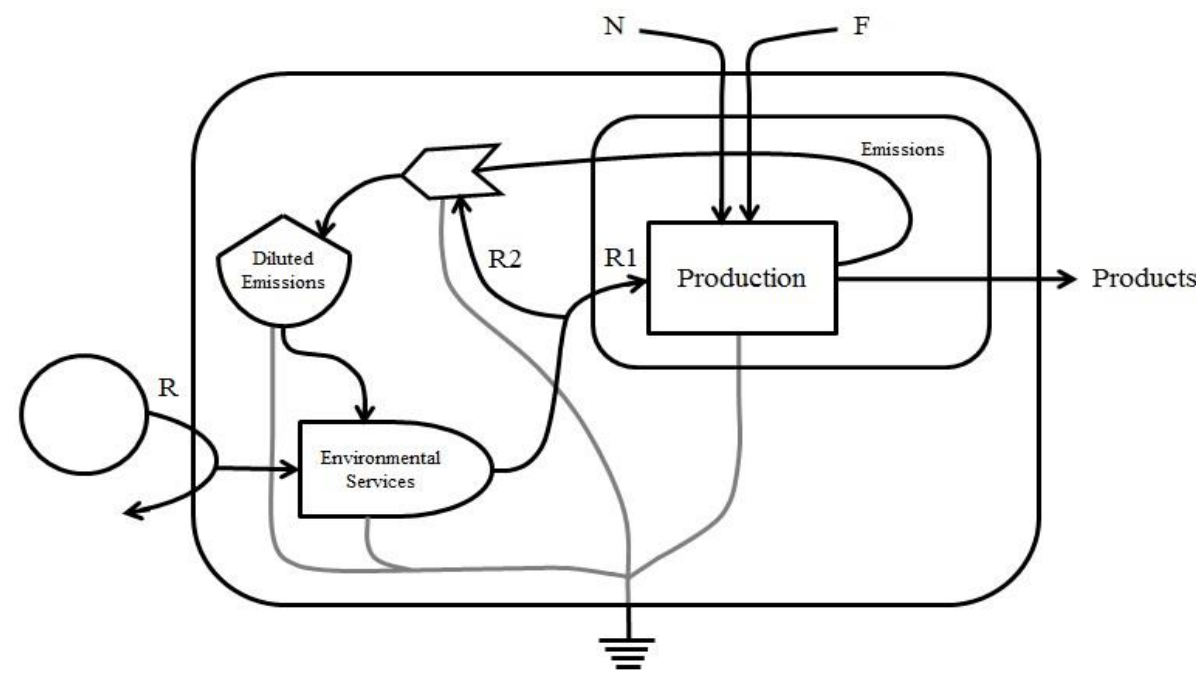

Fig. 1. - To drive production (poultry or aquaculture), flows of renewable $\left(\mathrm{R}_{1}\right)$, nonrenewable $(\mathrm{N})$ and purchased resources $(\mathrm{F})$ are needed (represented by - ) Emissions are diluted by nature through renewable services $\left(\mathrm{R}_{2}\right)$. Flows of energy dispersion is represented by -

\subsection{Systems Under Study}

The present study was carried in broiler houses located inland Mato Grosso do Sul state and a tilapia farm inland São Paulo state, Brazil. Necessary data to accomplish the study for both production systems were extracted from [11;12], respectively.

Average values of four commercial broiler houses (tunnel system ones) at Itaquiraí - MS county, were used to carry out the study. There were 25,200 broilers in each house from the Hubbard' genetic strain reared for 42 days until they reach the commercial weight of $2 \mathrm{~kg}$.

The tilapia (Genomar Supreme Tilapia) farm is located in Iperó city, distant from São Paulo city $128 \mathrm{~km}$. The installation is comprehensive of a total of 200 fish cages, 40 of $4 \mathrm{~m} 3$ and 60 of $6 \mathrm{~m} 3$ each. The pond where the cages are placed covers an area of 30 ha with an average depth of $2.10 \mathrm{~m}$. The pond is fed by a water course which pours a water supply of $150 \mathrm{l} / \mathrm{sec}$ in average. Fingerlings are placed into the cages and after a cycle of approximately 180 days, the fish reach $484 \mathrm{~g}$. The proper chemical analysis shows no eutrophication of pond water. The annual production is 320,000 fishes. Ammonia emission values were obtained from the application of a predicting model confirmed by measurements in loco [11]. Phosphorous release due to fish metabolism was estimated according to the conversion factor in biomass and the content of phosphorus in the food. Additional data were retrieved from literature. 


\section{Results and Discussion}

Table 1 shows the results of the environmental services involved in dilution of emissions accounted for both the enterprises.

Table 1. - Mass of air required to dilute ammonia emissions from the poultry house and mass of water required to dilute phosphorous released from the tilapia farm, on a yearly basis; energy values and corresponding annual emergy flows of the environmental services $\mathrm{R}_{2}$ expressed in seJ and seJ by $\mathrm{kg}$ of food produced.

\begin{tabular}{|c|c|c|}
\hline & $\begin{array}{l}\text { Poultry produc- } \\
\text { tion }\end{array}$ & Tilapia aquaculture \\
\hline Mass of air $(\mathrm{g} / \mathrm{y})$ & $6.20 \times 10^{14}(1)$ & \\
\hline Mass of water (g/y) & & $2.23 \times 10^{07}(5)$ \\
\hline Energy $(J / y)$ & $7.75 \times 10^{12}(2)$ & $1.06 \times 10^{14}(6)$ \\
\hline $\begin{array}{l}\text { Emergy from environmental services } \mathrm{R}_{2} \\
(\mathrm{seJ} / \mathrm{y})\end{array}$ & $1.95 \times 10^{16}(3)$ & $1.17 \times 10^{19}(7)$ \\
\hline $\begin{array}{l}\text { Emergy from environmental services } R_{2} \text { by } \\
\text { mass ( } \mathrm{seJ} / \mathrm{kg} \mathrm{y} \text { ) }\end{array}$ & $7.70 \times 10^{10}(4)$ & $7.50 \times 10^{13}(8)$ \\
\hline "Emergy eco-efficiency" (kg y/seJ 10-10) & 1.3 & 0.0013 \\
\hline
\end{tabular}

The OECD (OECD-Organisation for economic cooperation and development) has called eco-efficiency "the efficiency with which ecological resources are used to meet human needs" and defines it as a ratio of an output (the value of products and services produced by a firm, sector, or economy as a whole) divided by the input (the sum of environmental pressures generated by the firm, the sector, or the economy)." [13]. The concept was reformulated in emergy terms, and it was expressed as units of mass produced by seJ of environmental services committed to dilute pollutants $(\mathrm{kg} / \mathrm{seJ})$. Values can be seen in Table 1, calculated as the inverse of the emergy flows corresponding to the environmental services normalized by mass. At a first glance, poultry production seems to be a thousand times more "eco-efficient", according to the definition adopted here. However, although all the environmental services are accounted for by using a common metric, the present approach only takes into consideration dilution of pollutants in a simplified way. The inclusion of pollutants into biogenic cycles occurs, and kinetics of the diverse reaction should be considered. Even so, present results serve as a starting point to evidence that real efficiency of production systems are not adequately measured without taking into consideration the externalities caused by the use of resources, and release of by-products, even in compliance with legal threshold concentrations. Moreover, the degree of eco-efficiency attained is not just limited to an absolute value obtained by the index calculation but to a holistic enterprise management towards environmental improvement.

If it is assumed that the whole emergy required to dilute pollutants is derived from renewable resources supplied by region, the calculated "support area" will act as a sustainability predictor of long-term sustainability. Table 2 shows the values of "support area" and the ratio between them and the direct areas (real area of the enterprise being $1800 \mathrm{~m}^{2}$ for poultry production and 30 ha for aquaculture farm). 
Table 2. - The support area (As), the specific As (by mass) and the ratios between As and direct areas (DA), calculated for Poultry production and Tilapia aquaculture.

\begin{tabular}{lcc}
\hline & Poultry production & Tilapia aquaculture \\
\hline As $\left(\mathrm{m}^{2}\right)$ & $5.30 \times 10^{04}$ & $32.0 \times 10^{06}$ \\
As $\left(\mathrm{m}^{2} / \mathrm{kg}\right)$ & 0.21 & 206.5 \\
As/DA & 29 & 107 \\
\hline
\end{tabular}

When As by mass produced is considered differences between both systems are evidenced. Each kilogram of tilapia produced relies on almost a thousand times more support area than poultry. According to emergy theory, transformity related to water capacity for diluting solutes are higher than transformity for the wind, the environmental service involved for ammonia dilution. The hierarchies of environmental processes that originate both services are different, and comparison should be made carefully. Even so, the As/DA ratio evidences that the direct area is not a good indicator to attain the real contribution of the biosphere when acting as source and sink of resources. In this way, areas 29 times and more than hundred times greater than the direct areas respectively are need to support the enterprises just from the emissions, without taking into account resources side (or inputs).

\section{Concluding Remarks}

Accounting for the environmental services required to dilute emissions is shown to be as a necessary procedure towards the proper evaluation of the sustainability of processes and quantification of externalities.

The challenge is to fit humans' production patterns to the biosphere's capacity to absorb waste by-products, without overload. For this purpose, services provided by natural capital have to be adequately evaluated and finally quantified in terms comparable with the economy.

\section{References}

1. Food and Agricultural Organization of the United Nations: Global Agriculture Towards, http://www.fao.org/fileadmin/templates/wsfs/docs/Issues_papers/HLEF2050_Global_Agriculture.pdf

2. Gates, R. S., Xin, H., Casey, K. D., Y. Liang, Y., Wheeler, E. F.: Method for Measuring Ammonia Emissions from Poultry Houses. J. Appl. Poult. Res. 14, 622-634 (2005)

3. Naylor, R., Burke, M.: Aquaculture and Ocean Resources: Raising Tigers of the Sea. Annu. Rev. Environ. Resour. 30, 185-218 (2005)

4. Odum H.T.: Environmental Accounting: Emergy and Environmental Decision Making. John Wiley \& Sons Ltd, New York (1996)

5. Ulgiati, S., Brown, M.T.: Quantifying the Environmental Support for Dilution and Abatement of Process Emissions. Journal of Cleaner Production, 10, 335-348 (2002) 
6. Lou, B., Qiu, Y., Ulgiati, S.: Emergy-based Indicators of Regional Environmental Sustainability: A Case Study in Shanwei. Ecological Indicators, 57, 514-524 (2015)

7. Brown, M.T., Ulgiati, S.: Emergy-based Indices and Ratios to Evaluate Sustainability: Monitoring Economies and Technology Toward Environmentally Sound Innovation. Ecological Engineering, 9, 51-69 (1997)

8. Odum H.T., Brown M.T., Brandt-Williams S.: Introduction and Global Budgets, Folio \#1. University of Florida (2000)

9. Odum, H.T.: Emergy Evaluation of Salmon Pen Culture. University of Florida Press (2001)

10. Demétrio, F. J. C., Giannetti, B. F., Bonilla, S. H., Almeida, C.M. V. B.: Emergy Accounting of Brazilian States and Regions. In: Brown, M.T. et al. (Eds), Emergy Synthesis 7: Theory and Applications of the Emergy Methodology. Gainesville, FL. 413-418 (2013)

11. Lima, N., Garcia, R., Nääs, I., Caldara, F., Ponso, R.: Model-predicted Ammonia Emission from two Broiler Houses with Different Rearing Systems. Scientia Agricola, 72(5), 393-399 (2015)

12. Pierobom, J. L.: Estudo da Sustentabilidade Ambiental em Diferentes Sistemas de Criação de Tilápias. Universidade Paulista. (2009)

13. OECD: Eco-efficiency, http://www.oecdbookshop.org

14. Buenfil, A. A.: Emergy Evaluation of Water. University of Florida (2001) 